\title{
MERUMUSKAN DAN MENGEMBANGKAN PERENCANAAN PEMASARAN BISNIS SALAD BUAH DAN DESSERT BOX CHOCOLATE
}

\author{
Gustian Mahardika Pratama \\ NIM 031200418
}

Untuk mempertajam dan memperdalam pemahaman tentang konsep dan strategi perencanaan pemasaran suatu bisnis atau produk, survey atau observasi lapangan kepada pelaku bisnis kecil dapat digunakan dalam proses pembelajaran, dengan harapan fakta operasional bisnis kecil dalam merencanakan dan mengembangkan bisnis dapat tergambar dengan jelas.

Berikut ini adalah Panduan singkat untuk melakukan Observasi lapangan tersebut:

Setiap Mahasiswa melakukan survey dan wawancara kepada 1 (satu) orang pelaku bisnis kecil dan menengah (UKM) yang operasionalisasinya masih dijalankan.

Hal-hal yang perlu ditanyakan saat wawancara adalah :

1. Produk apa yang dijual

2. Berapa Harga jual produk

3. Bentuk Promosi apa yang dilakukan (contoh: potongan harga bagi pelanggan, menghias booth/gerobak tempat berjualannya, dsb)

4. Bentuk pendistribusian yang dilakukan. (contoh: layanan antar ke tempat pemesan)

Berdasarkan hasil wawancara tersebut, buatlah usulan perencanaan pemasaran terkait :

a. Perencanaan Pemasaran Pengembangan Produk yang dijual UKM tersebut (contoh: inovasi produk, kemasan). Orientasikan produk dijual secara online

b. Perencanaan Pemasaran Penetapan Harga jual produk tersebut (contoh: menggunakan penetration pricing yang dihubungkan dengan daur hidup produk)

c. UKM tersebut (contoh: menggunakan media sosial, dengan tetap memperhatikan Perencanaan Pemasaran bentuk promosi yang tepat dilakukan karakteristik produknya)

d. Perencanaan pemasaran penggunaan saluran distribusi agar konsumen dapat mengakses produk tersebut (Contoh: menyediakan layanan pesan-antar)

Hasil wawancara dan rumusan perencanaan pemasaran ditulis rapi menggunakan Ms Word, lalu di-submit ke dalam sistem elearning UT disertai dengan Gambar/Photo UKM-nya. 


\section{Hasil Wawancara terhadap Usaha Penjualan Salad Buah dan Dessert Box Chocolate}

Narasumber : Bela Maulia

Jenis Usaha : Penjualan produk makanan berupa salad buah dan Dessert Box Chocolate

Hasil Wawancara:

Pewawancara $\quad$ : "Selamat pagi Mbak Bela, boleh saya bertanya tentang usaha penjualan produk yang anda lakukan saat ini?”

Narasumber : :Iya boleh mas"

Pewawancara : :Pertama, saya ingin bertanya sejak kapan anda memiliki ide untuk menggeluti usaha anda saat ini?"

Narasumber : "Awalnya saya mendapat tawaran dari koperasi kantor, untuk menyuplai makanan yang untuk dijual pada kantin kejujuran di kantor. Kemudian saya mendapat ide untuk meminta bantuan ibu saya di rumah untuk membuat salad buah dan menjualnya di kantin kejujuran kantor."

Pewawancara : :Selain salad buah apa lagi yang mbak Bela jual?"

Narasumber : : "Untuk pertama kali, saya hanya menyediakan salad buah saja. Tetapi lama kelamaan muncul permintaan dari rekan-rekan kantor untuk menyediakan pencuci mulut lain. Alhasil saya pun kembali berkreasi dengan membuat menu baru berupa dessert box chocolate yang enak dihidangkan sebagai pencuci mulut.”

Pewawancara : : "Jadi sampai saat ini ada dua produk andalan yang dijual mbak Bela ya.. yaitu salad buah dan dessert box chocolate."

Narasumber : "Iya benar mas.."

Pewawancara $\quad$ : "Berapa harga jual yang mbak Bela tetapkan untuk produk yang dijual ini?" 
Narasumber

Pewawancara

Narasumber

Pewawancara

Narasumber

Pewawancara

Narasumber

Pewawancara

Narasumber
: "Untuk salad buah dijual dengan harga Rp 10.000,00 sementara untuk dessert box chocolate seharga Rp 15.000,00.”

: "Bagaimana cara melakukan promosi agar produk tersebut dapat diketahui oleh para konsumen yang menjadi sasaran penjualan mbak Bela?"

: "Saya memanfaatkan media sosial seperti Whatsap, Twitter, dan Instagram dengan memposting foto produk yang saya jual.”

: "Sampai saat ini apakah mbak Bela masih aktif melakukan penjual dua produk tersebut?"

: "Iya sampai saat ini saya masih aktif menjual salad buah dan dessert box chocolate ini mas. Selain dijual kepada para karyawan di kantor melalui kantin kejujuran, saya juga menitipkan produk saya ke beberapa tempat lainnya dan juga melayani pemesanan dalam jumlah banyak.”

: "Jadi mbak Bela sendiri yang melakukan pendistribusian produk-produk tersebut kepada konsumen?"

: "Untuk produk yang dititipkan di beberapa tempat biasanya saya antarkan langsung mas, tetapi untuk pemesan yang tempatnya agak jauh saya menggunakan layanan Go Send untuk mengantarkannya.

: "Baik mbak Bela, terima kasih atas informasi yang telah disampaikan kepada saya tentang usaha yang mbak Bela lakukan saat ini. Semoga kedepannya nanti usaha mbak Bela dapat semakin berkembang."
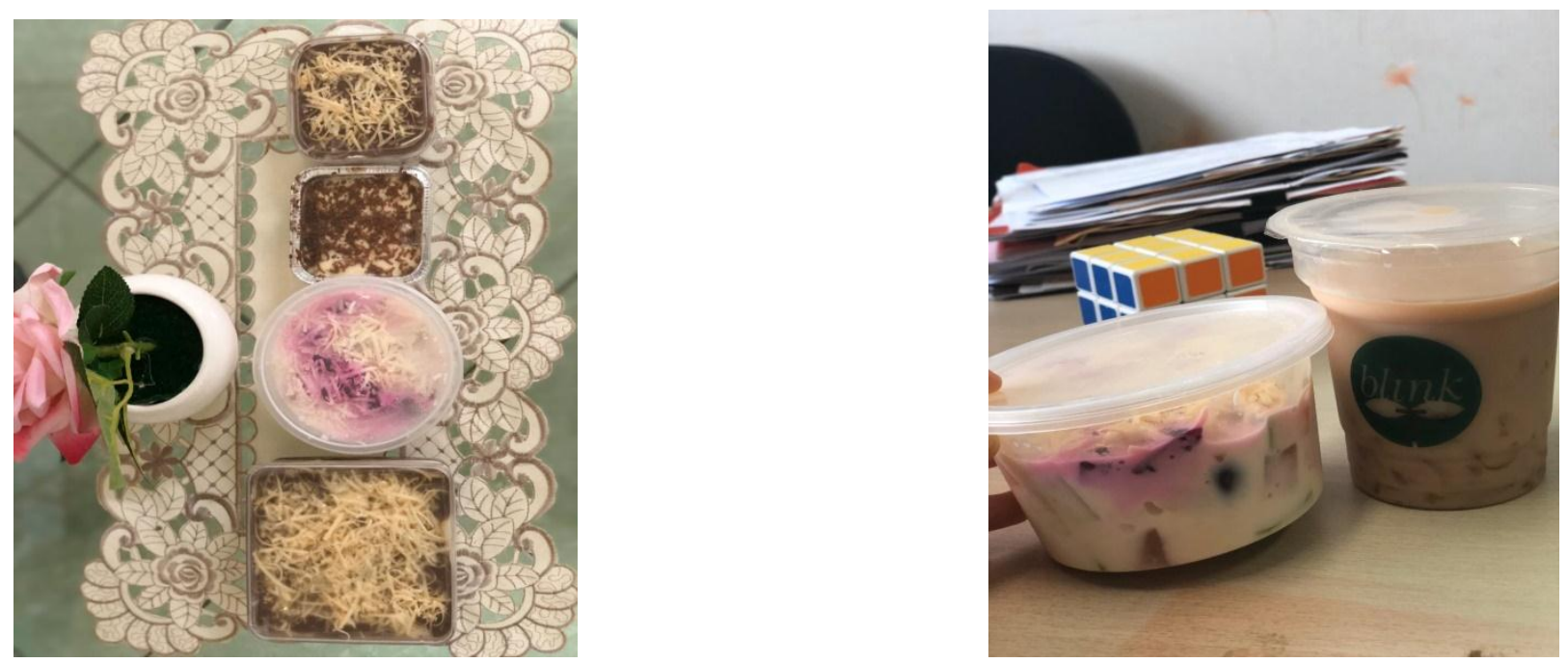


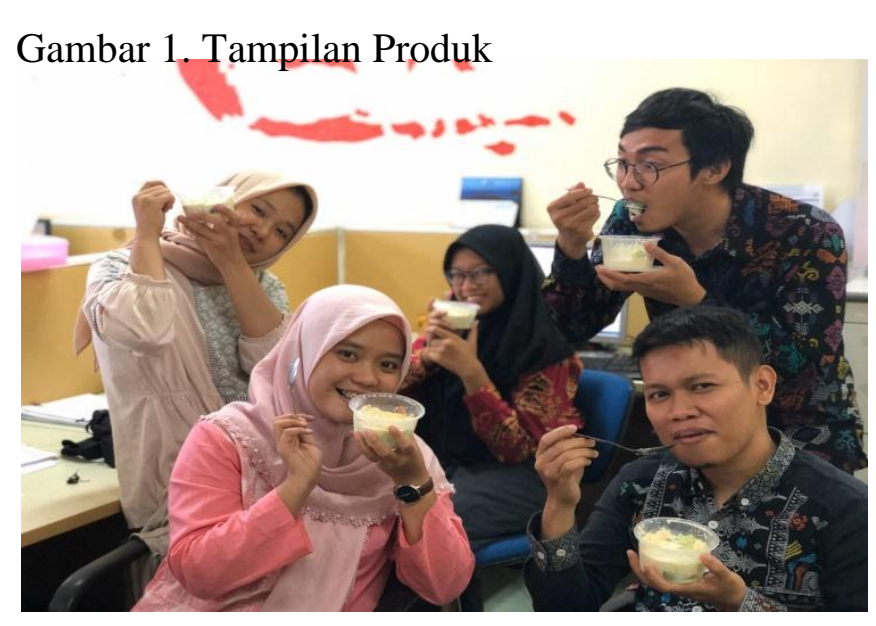

Gambar 3. Tampilan Testimoni Konsumen

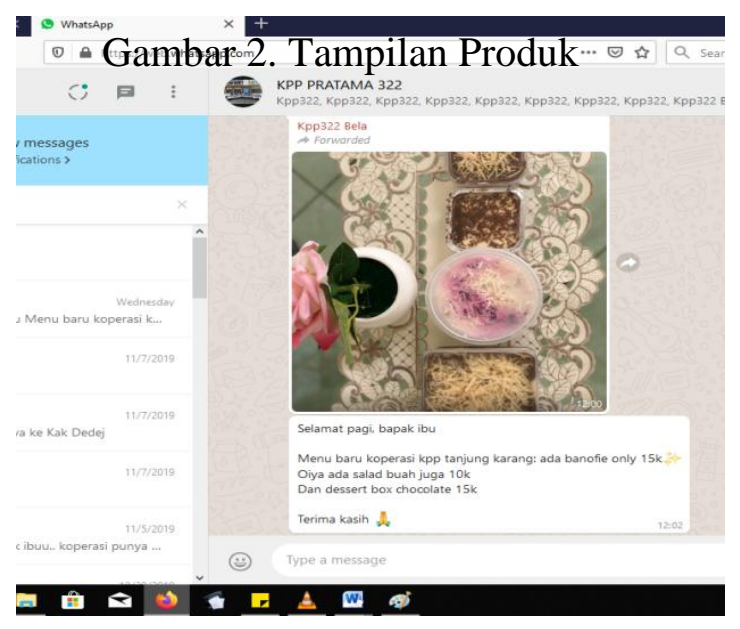

Gambar 4. Promosi Melalui Whatsapp

\section{Berdasarkan hasil wawancara tersebut, buatlah usulan perencanaan pemasaran terkait :}

a. Perencanaan Pemasaran Pengembangan Produk yang dijual UKM tersebut (contoh: inovasi produk, kemasan). Orientasikan produk dijual secara online Jawab:

Produk makanan berupa salad buah dan dessert chocolate box merupakan produk makanan yang mudah dijual dan dapat diterima oleh sebagian besar konsumen. Saat ini telah banyak produsen yang menjual produk serupa.

Oleh karena itu, untuk membedakan dengan produk pesaing, perlu dibuatkan kemasan khusus untuk produk salad buah dan dessert chocolate box buatan mbak Bela. Kemasan dapat tetap menggunakan mangkuk/box plastik dengan sticker merk buatan mbak Bela. Dengan adanya sticker tersebut, produk mbak Bela dapat dengan mudah diingat oleh konsumen sekaligus dapat dijadikan sebagai media promosi produk tersebut.

b. Perencanaan Pemasaran Penetapan Harga jual produk tersebut (contoh: menggunakan penetration pricing yang dihubungkan dengan daur hidup produk) Jawab: 
Setelah melakukan beberapa riset terkait harga jual produk pesaing, diketahui bahwa ratarata harga jual produk salad buah dan dessert sejenis di kota Bandar Lampung berkisar Rp 15.000,00 hingga Rp 25.000,00.

Untuk masa awal penjualan produk, harga yang ditawarkan mbak Bela untuk produk salad sebesar Rp 10.000,00 dan dessert chocolate box sebesar Rp 15.000,00 dirasa sudah cukup baik. Harga tersebut tidak terlalu mahal bagi produk yang baru saja ditawarkan jika dibandingkan dengan harga produk yang sudah ada terlebih dahulu.

Ditetapkan harga semurah mungkin bertujuan agar produk dapat diterima dengan mudah oleh konsumen, sehingga konsumen dapat terus melakukan pembelian terhadap produk tersebut.

c. UKM tersebut (contoh: menggunakan media sosial, dengan tetap memperhatikan Perencanaan Pemasaran bentuk promosi yang tepat dilakukan karakteristik produknya) Jawab:

Produsen melakukan promosi dengan menggunakan media sosial seperti Whatsapp, Twitter, dan Instagram. Selain tidak mengeluarkan biaya, promosi melalui media sosial tersebut juga dirasa lebih efektif menjangkau sasaran konsumen.

d. Perencanaan pemasaran penggunaan saluran distribusi agar konsumen dapat mengakses produk tersebut (Contoh: menyediakan layanan pesan-antar)

Jawab:

Produsen produk salad dan dessert chocolate box saat ini melakukan distribusi langsung kepada para konsumennya. Selain dapat langsung ke tempat-tempat produk dijual, konsumen juga dapat memesan produk dan meminta agar produk tersebut diantar langsung ke tempat konsumen berada. Mbak Bela menggunakan jasa pihak ketiga, yaitu layanan Go Send untuk mengantarkan pesanan kepada para konsumen.

\section{Referensi :}

Mulyana, M., Hidayat, L., \& Puspitasari, R. (2019). Mengukur Pengetahuan Investasi Para Mahasiswa Untuk Pengembangan Galeri Investasi Perguruan Tinggi. JAS-PT (Jurnal Analisis Sistem Pendidikan Tinggi Indonesia), 3(1), 31-52. 
Binangkitsari, L. (2018). The Influence of Brand Equity Elements on Purchase Decision and Its Imlication on Customer Loyalty.

Sulistiono, S., \& Bawono, S. (2009). Membangun Strategi Promosi Dalam Pengembangan Bisnis. Jurnal Ilmiah Kesatuan (JIK), 11(2).

Munawar, A., \& Purba, J. H. V. (2006). Kajian Dampak Pelatihan terhadap Kinerja Karyawan. Jurnal Ilmiah Kesatuan Nomor, 8(7), 2.

Munawar, A., \& Marpaung, B. S. (2013). Pengaruh Arus Kas Operasi Terhadap Peningkatan Kemampulabaan dan Pertumbuhan Perusahaan. Jurnal Ilmiah Manajemen Kesatuan, $1(3)$.

Pamungkas, B., \& Mustikawati, D. S. (2015). Analisis Penerapan PSAK 45 (Revisi 2011) Terhadap Penyusunan Laporan Keuangan Entitas Nirlaba (Studi Kasus pada Yayasan Dharma Setia Kosgoro). Jurnal Ilmiah Akuntansi Kesatuan, 3(2), 101-110.

Fadillah, A., Sujana, S., \& Sukartaatmadja, I. (2019). Kajian Minat Studi Lanjut Siswa-Siswi SMA dan SMK Kota Bogor Ke Perguruan Tinggi. JAS-PT (Jurnal Analisis Sistem Pendidikan Tinggi Indonesia), 3(1), 53-62.

Pauziah, P., \& Mulyana, M. (2018). Formulation of The Green Marketing Development Strategy for the Body Shop Botani Square Bogor. In THE INTERNATIONAL CONFERENCE ON ACCOUNTING AND MANAGEMENT SCIENCE (p. 171).

Maulana, M. A., Iriyadi, I., \& Nurjanah, Y. (2018). Financial Reporting for Micro Small and Medium Enterprises Towards Industrial Revolution Era 4.0. In THE INTERNATIONAL CONFERENCE ON ACCOUNTING AND MANAGEMENT SCIENCE (p. 32-38). 